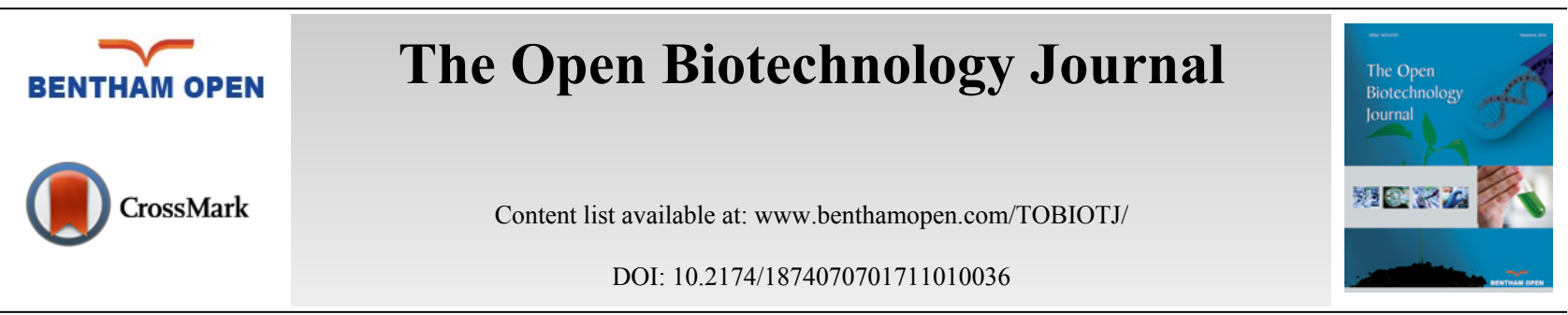

RESEARCH ARTICLE

\title{
Biomethanization of Cattle Manure, Pig Manure and Poultry Manure Mixture in Co-digestion with Waste of Pineapple Fruit and Content of Chicken-Gizzard- Part I: Kinetic and Thermodynamic Modelling Studies
}

\author{
O. A. Aworanti ${ }^{1}$, S. E. Agarry ${ }^{2, *}$ and O. O. Ogunleye ${ }^{1}$ \\ ${ }^{I}$ Biochemical and Chemical Engineering Biotechnology Laboratory, Department of Chemical Engineering, Ladoke \\ Akintola University of Technology, P. M. B. 4000, Ogbomoso, Nigeria. \\ ${ }^{2}$ Biochemical and Bioenvironmental Engineering Laboratory, Department of Chemical Engineering, Delta State \\ University, Abraka, P.M.B. 22, Oleh Campus, Nigeria
}

Received: January 29, 2017

Revised: March 27, 2017

Accepted: April 27, 2017

\begin{abstract}
:
Background:

The increased energy consumption from fossil fuels with its attendant gas emissions and environmental problems has provided the impetus to exploit new energy source that are renewable and environmentally-friendly.
\end{abstract}

\section{Objective:}

This work focused on the investigation and evaluation of the single or individual effects of feed-inoculum ratio, temperature, and agitation speed (i.e. operating variables) on biomethanization of the mixture of cattle manure, pig manure and poultry manure (mixed animal wastes) co-digested with pineapple fruit waste and content of chicken-gizzard (inoculum) as well as to model the kinetics of biomethanization at these different operating variables and to determine the thermodynamic properties of the biomethanization process.

\section{Method:}

The biomethanization experiments were carried out in anaerobic biodigesters at operating variables of feed/inoculums ratio that ranged from $1: 1$ to $3: 1$, temperature from 25 to $60^{\circ} \mathrm{C}$, and agitation speed from $30-70 \mathrm{rpm}$ using one factor at a time (OFAT) method. The biodigesters were incubated for 70 days retention time.

\section{Result:}

The feed/inoculum ratio, temperature and agitation speed had positive impact on cumulative biogas yield, biomethane content and start-up time of biomethanization. The cumulative biogas yield and biomethane content achieved with agitation speed of 30 to $70 \mathrm{rpm}$ was respectively higher than the biogas yield and biomethane content attained without agitation. Minimum cumulative biogas yield and biomethane content was respectively obtained with feed/inoculum ratio of $1: 1$, temperature of $25^{\circ} \mathrm{C}$ and agitation speed of $70 \mathrm{rpm}$; while maximum cumulative biogas yield with its biomethane content was attained with feed/inoculum ratios of $1: 3$ and $3: 1$, temperature of $60^{\circ} \mathrm{C}$ and agitation speed of $30 \mathrm{rpm}$, respectively. Modified Gompertz and Exponential Rise to Maximum kinetic models fitted very well to the data and thus showed better correlation of cumulative biogas production. The thermodynamic parameters of Gibbs free energy, enthalpy, entropy change and activation energy of biomethanization were estimated and evaluated, and was found that the biomethanization process was thermodynamically feasible, spontaneous and endothermic in nature suggesting hydrogenotrophic methanogenesis pathway. The activation energy of the biomethanization process was found to be

\footnotetext{
* Address correspondence to this author at the Biochemical and Bioenvironmental Engineering Laboratory, Department of Chemical Engineering,
} Delta State University, Abraka, P.M.B. 22, Oleh Campus, Nigeria; Tel: +2348055529705; E-mail: sam_agarry@yahoo.com 
$3.324 \mathrm{~kJ} / \mathrm{mol}$. The specific heat capacity at constant volume and constant pressure, specific internal energy and specific enthalpy of the biogas and biomethane content increased with increase in temperature.

\section{Conclusion:}

Biogas/biomethane production from the biomethanization of mixed animal wastes co-digested with fruit waste and inoculum is a feasible, viable and sustainable renewable energy option that can be simulated by kinetic models and influenced by operating variables.

Keywords: Animal waste, Biogas, Biomethane Content, Process variables, Kinetics, Thermodynamics.

\section{INTRODUCTION}

Biomass and their wastes, depending on their characteristics, can be converted into energy and/or fuel by combustion, gasification, co-firing with other fuels and ultimately by anaerobic digestion [1]. Anaerobic digestion converts the biological materials or biomass materials (organic matter) to biogas through the following four steps: hydrolysis, acidogenesis, acetogenesis and methanogenesis [2 - 5]. The process and mechanism of anaerobic digestion (biomethanization) is carried out by a consortium of micro-organisms and also the activity of biomethanization process and biogas yield depends on various factors like temperature, $\mathrm{pH}$, concentration of substrate/nutrients, agitation, pretreatment of feedstock, hydraulic retention time, total solid content, organic loading rate and the carbon: nitrogen $(\mathrm{C} / \mathrm{N})$ ratio [5, 6]. All these factors need proper monitoring and control to achieve maximum yield of biogas [7].

Anaerobic digestion mainly takes place at either mesophilic $\left(25-40^{\circ} \mathrm{C}\right)$, or thermophilic temperatures $\left(45-60^{\circ} \mathrm{C}\right)[8$, 9]. Though, there have been some few studies on the effect of temperature on biogas production [10 - 13]. Agitation is vital to maintaining intimate contact between the bacteria and the substrate in order to encourage more active metabolism [14]. It is also useful in setting free gases that will be trapped in the substrates, and exposing fresh bacteria to fresh substrates. The most important objectives of agitation are; removal of metabolites produced by methanogens (gas), mixing of fresh substrate and bacterial population (inoculation), prevention of scum or foam formation and sedimentation, avoidance of pronounced temperature gradients within the digester (i.e. uniform heat or temperature distribution), provision of uniform bacterial population density and prevention of the formation of dead spaces that would reduce the effective digester volume [15 - 17]. There are different methods through which agitation or stirring/mixing can be achieved and this includes the use of mechanical agitators or mixers, pneumatic agitators/mixers, hydraulic agitators, recirculation of digesters contents or recirculation of produced biogas using recirculation pumps $[18,19]$. The major factors that affect agitation/stirring are the agitation strategy, agitation intensity and duration as well as the location of the agitator or stirrer [17]. Many workers have reported on the effects of agitation/mixing on the yield of biogas and performance of anaerobic biodigesters. Some of these workers like Desai et al., Karim et al., Angelidaki, Kaparaju et al. and El-Bakhshwan et al., respectively reported the positive effect of agitation or mixing either in minimal or intermittent form on biogas production while others reported negative influence and no significant or considerable effect on biogas yield, when agitation is in the continuous form [17 - 26]. Hoffmann et al. further reported that continuous agitation impacted negatively on the performance of the anaerobic biodigester [25]. However, because of these conflicting or contradictory results reported in the literature on the effect of agitation/mixing on biogas yield, thus there is the need for extensive investigation on the agitation of biodigester contents.

Anaerobic co-digestion of biomass wastes has been reported to enhance and/or improve the cumulative yield of biogas than mono-digestion [27 - 30]. Co-digestion of animal waste with other biodegradable organic waste as cosubstrate has been reported. For example, co-digestion of cattle manure with food waste, cow dung with fruit waste, food waste and vegetable waste, $\mathrm{pig} / \mathrm{swine}$ manure with grass silage and grass clippings and chicken droppings/manure with Cymbopogon citratus, water hyacinth and municipal sewage sludge [28, 29, 31 - 36]. All the above workers made use of the animal waste in their individual form without mixing with other form of animal waste and the type of fruit waste used as co-substrate by some of these workers was not stated. Prakash and Singh have reported that co-digestion of cow dung with vegetable waste in ratio 1:1 and its co-digestion with fruit waste in ratio 2:1 respectively gave the highest biogas yield [28]. However, co-digestion of cow dung, chicken manure, and pig manure and sewage waste has been reported by Sebola et al. and they observed that ratio 1:1:1:1 gave the highest biogas yield [37].

In the start-up of biogas production in biodigesters, a balanced microbial population ratio of acetogenic bacteria and methanogenic bacteria is a requirement. This requirement of a balanced microbial population and the slow rate of methanogenic bacteria growth are the fundamental problems in biodigester start-up [38]. The slow rate of methanogenic bacteria increases the required time for an equilibrium establishment between acetogenic bacteria and methanogenic 
bacteria and thus results in intermediate biodegradation products accumulation (e.g. volatile fatty acid and dissolved hydrogen) [39]. The presence of excess volatile fatty acids brings about the lowering of the $\mathrm{pH}$ and thus inhibits the rate of methanogenic bacteria growth [38], which subsequently results in delayed start-up or biodigester failure as well as reduced/low biogas yield. Hence, to avoid these problems, the bacterial community should contain sufficient levels of methanogenic bacteria. Several studies had emphasize on the importance of inoculums in anaerobic biodigestion [40, 41]. Very few works have reported the effect of co-substrate in conjunction with the use of inoculums on biogas production yield and start-up in anaerobic biodigester using animal manure as major feedstock [5, 42]. The duration of start-up phase and biogas yield depends on the type of feedstock and inoculums. The use of chicken rumen or chickengizzard content and rumen fluid from slaughter house has been found to be suitable for enhancing biogas production from animal manure [5, 42]. However, in most of these studies, modeling the kinetics and determining the thermodynamic properties of biogas generation were not carried out.

These observations from the above studies informed our decision to investigate the effects of biological additives, $\mathrm{pH}$ and total solid content on biomethanation of animal wastes made up of the mixture of cow dung, pig dung and poultry droppings in co-digestion with fruit wastes (mango, orange and pineapple) and chicken rumen as inoculum which has been reported elsewhere [5]. It was observed from the study that co-digestion of the animal waste with pineapple fruit waste at the different $\mathrm{pH}$ and total solid content provided the highest biomethane yield as compared to that of mango, orange and the mixture of orange, mango and pineapple fruit wastes, respectively.

Nevertheless, more information on the effects of feed/inoculum ratio and agitation speed on biomethane/biogas yield and start-up time for biogas generation is still needed. Information on the kinetics of renewable waste biomethanization/anaerobic digestions is of paramount importance and a key factor for understanding biomethanization or methanogenesis process, measurement of biomethanization speed, design and development of efficient anaerobic digester for a renewable waste conversion. Therefore, in continuation of our previous studies, the objectives of this study are to investigate and evaluate the single or individual effects of feed-inoculum ratio, temperature, and agitation speed (using one factor at a time (OFAT) method) on biomethanization of the mixture of cattle dung, pig dung and poultry droppings (mixed animal wastes) co-digested with pineapple fruit waste and content of chicken-gizzard (inoculums) as well as to model the kinetics of biomethanization at these different operating variables and to determine the thermodynamic properties of the biomethanization process. Animal manures have been established as suitable to be used as a carrier substrate due to its high buffering capacity that regulate the optimum $\mathrm{pH}$ in the reactor, and the high level of nutrient, micronutrients and other trace elements that enhance optimal bacteria growth [43]. Moreover, large proportion of the agricultural sector in both developing and developed countries is involved with livestock and poultry farming which results in large quantities of animal manure and other wastes which calls for public, environmental and social concerns $[44,45]$.

\section{MATERIALS AND METHODS}

\subsection{Feedstock Collection and Preparation}

Animal wastes made up of cattle dung, pig dung and poultry droppings were collected from LAUTECH agricultural farm, Ogbomoso, Oyo State, Nigeria. The pineapple fruit wastes were collected from Bodija market, Ibadan, Oyo state, Nigeria. While the content of chicken-gizzard (used as inoculum) was collected from Mokola market, Ibadan, Oyo State, Nigeria. The samples collected were maintained in a refrigerator at $4{ }^{\circ} \mathrm{C}$ to avoid microbial action until further use. The substrates (mixed animal wastes) and co-substrates (pineapple fruit waste and chicken inoculum) were prepared according to the method of Iyagba et al. [46]. The substrates and co-substrate were washed, sundried for twenty days; oven dried at $105^{\circ} \mathrm{C}$ for $24 \mathrm{~h}$ and then mechanically crushed using a mortar and pestle to ensure homogeneity. Table 1 shows the physical and chemical characterization of the animal wastes, pineapple fruit wastes and inoculum. The characterization was carried out according to standard methods [47, 48]. The parameter that can be used to describe the suitability of a substrate for anaerobic fermentation or digestion is the carbon-nitrogen $(\mathrm{C} / \mathrm{N})$ ratio. It has been reported that very high $\mathrm{C} / \mathrm{N}$ ratio in an anaerobic digester can result in a too low nitrogen concentration for microbial growth [49] as well as result in the consumption of nitrogen by the methanogens for protein production while some leftover carbon will remain unreacted, thereby leading to low biogas generation [50]. In contrast, a low $\mathrm{C} / \mathrm{N}$ ratio can lead to ammonia nitrogen accumulation which can result in the digestion process inhibition [49]. Thus, it has been reported that the optimal $\mathrm{C} / \mathrm{N}$ ratio for anaerobic digestion ranges from 20 to 30:1 [49]. Table 1 shows that the $\mathrm{C} / \mathrm{N}$ ratios of cattle manure, pig manure and chicken manure are lower than the required optimum while the $\mathrm{C} / \mathrm{N}$ ratio of the pineapple fruit waste is higher and thus can serve as a co-substrate to improve the overall $\mathrm{C} / \mathrm{N}$ ratio of the anaerobic 
biodigester feed ingredient. The microbial species present in the feedstock were also characterized and identified according to standard methods. The results of the characterization and micro-organisms identified in each of the feedstock waste; pineapple fruit waste, cattle manure, pig manure, and poultry manure were predominantly bacteria and they are Escherichia coli, Staphylococcus species, Salmonella species, Bacillus species, Lactobacillus species, Flavobacterium species, Methanobacterium species and Pseudomonas species. The presence of these organisms in the waste may be as a result of the type of nutrient in the waste and the physical-chemical properties of the wastes [7, 11]. The chicken-gizzard content, as inoculum and source of microorganisms' surplus was used to improve the performance of the biodigester. The microorganisms identified in the chicken-gizzard content include, Escherichia coli, Bacillus species, Lactobacillus species, and Flavobacterium species.

Table 1. Physical and chemical characterization of animal wastes, pineapple fruit wastes and inoculum.

\begin{tabular}{|c|c|c|c|c|c|}
\hline Parameters (\%) & Cattle Dung & Pig Dung & Poultry Dung & Pineapple Waste & Inoculum \\
\hline Dry Matter & 91.85 & 87.79 & 88.95 & 93.26 & 85.68 \\
\hline Organic Dry Matter & 95.97 & 95.29 & 94.74 & 96.88 & 94.08 \\
\hline Nitrogen $^{a}$ & 1.69 & 1.627 & 0.508 & 0.204 & 0.539 \\
\hline Ammonium Nitrite $^{a}$ & 0.911 & 0.825 & 0.407 & 0.256 & 0.479 \\
\hline Phosphorous $^{a}$ & 0.029 & 0.038 & 0.034 & 0.042 & 0.027 \\
\hline $\mathrm{pH}^{\mathrm{a}} *$ & 6.11 & 6.49 & 6.35 & 5.03 & 6.18 \\
\hline Moisture $^{a}$ & 8.15 & 12.21 & 11.05 & 6.74 & 14.32 \\
\hline Crude Protein & 12.68 & 16.89 & 25.79 & 4.15 & 9.89 \\
\hline Crude Fat & 1.51 & 2.02 & 1.81 & 1.84 & 2.69 \\
\hline Carbohydrate & 25.94 & 21.88 & 23.72 & 63.81 & 8.75 \\
\hline Carbon/Nitrogen* & 17.62 & 14.58 & 9.63 & 42.80 & 17.08 \\
\hline Total Acetic Acid $^{\mathrm{a}}$ & 0.285 & 0.217 & 0.264 & 0.481 & 0.279 \\
\hline Crude Fibre & 38.29 & 14.85 & 0.471 & 11.64 & 1.86 \\
\hline Potassium & 0.527 & 0.392 & 0.472 & 0.725 & 0.169 \\
\hline Lignin & 16.85 & 15.31 & 17.89 & 13.28 & 1.88 \\
\hline Hemicellulose & 24.89 & 23.57 & 26.41 & 17.23 & 2.94 \\
\hline Carbon $^{a}$ & 35.49 & 39.40 & 39.74 & 28.43 & 18.79 \\
\hline
\end{tabular}

N.B: The parameter with superscript 'a' was analyzed in wet basis and parameter with asterisk * has no unit.

\subsection{Apparatus Set-Up and Experimental Procedure}

The biodigester experimental set-up for the biogas/biomethane production is as shown in Fig. (1).



Fig. (1). The experimental set-up for biogas/biomethane production.

Three holes were drilled on the lid to serve as inlet valve for loading the feed, outlet valve for the collection of biogas produced and a central hole which accommodate the shaft of a stirring system (Model: RW 16 Basic I KA) with a speed range of 10 to100 rpm. Two rubber hoses was each connected to the inlet valve for injection of feed substrates and the other connected to the outlet valve through which the biogas produced will be collected into a gas bag 
connected to it. The rubber hose connected to the gas bag is airtight, and has a three-way valve that can be opened to collect gas samples. A digital $\mathrm{pH}$ meter was used to measure $\mathrm{pH}$ of the digested slurry and a thermocouple was used as a heating element for the digester. The digester was equipped with a control panel which permits the regulation of temperature and agitation. Efficient agitation was achieved by propeller with flat stirring paddles and four vertical baffles.

Fifteen anaerobic biodigesters labeled D1 to D15 with a working capacity of $12 \mathrm{~kg}$ were used. Each biodigester was operated at a given operating variable while keeping other variables constant (i.e. one variable or factor at a time). The fermentation slurry was prepared according to the composition and given amount or quantity as presented in Table (2), and then charged into the respective biodigester. The biodigesters were incubated for 70 days (i.e. 10 weeks) retention time.

Table 2. Composition of materials in each digester at different process variables.

\begin{tabular}{|c|c|c|c|c|c|c|c|}
\hline \multirow[t]{2}{*}{ Digester } & \multirow[t]{2}{*}{ Parameter } & \multicolumn{6}{|c|}{ Substrate (kg) } \\
\hline & & Cow Dung & Pig Dung & Poultry Droppings & Chicken Rumen & Pineapple Fruit Waste & Water \\
\hline D1 & $\mathrm{F} / \mathrm{I}=1: 1$ & 0.61 & 0.61 & 0.61 & 2.44 & 0.61 & 7.12 \\
\hline $\mathrm{D} 2$ & $\mathrm{~F} / \mathrm{I}=1: 2$ & 0.41 & 0.41 & 0.41 & 3.25 & 0.41 & 7.12 \\
\hline D3 & $\mathrm{F} / \mathrm{I}=1: 3$ & 0.81 & 0.81 & 0.81 & 1.64 & 0.81 & 7.12 \\
\hline $\mathrm{D} 4$ & $\mathrm{~F} / \mathrm{I}=2: 1$ & 0.31 & 0.31 & 0.31 & 3.66 & 0.31 & 7.12 \\
\hline D5 & $\mathrm{F} / \mathrm{I}=3: 1$ & 0.92 & 0.92 & 0.92 & 1.22 & 0.92 & 7.12 \\
\hline D6 & $\mathrm{T}=25^{\circ} \mathrm{C}$ & 0.61 & 0.61 & 0.61 & 2.44 & 0.61 & 7.12 \\
\hline D7 & $\mathrm{T}=30^{\circ} \mathrm{C}$ & 0.61 & 0.61 & 0.61 & 2.44 & 0.61 & 7.12 \\
\hline $\mathrm{D} 8$ & $\mathrm{~T}=40^{\circ} \mathrm{C}$ & 0.61 & 0.61 & 0.61 & 2.44 & 0.61 & 7.12 \\
\hline D9 & $\mathrm{T}=50^{\circ} \mathrm{C}$ & 0.61 & 0.61 & 0.61 & 2.44 & 0.61 & 7.12 \\
\hline D10 & $\mathrm{T}=60^{\circ} \mathrm{C}$ & 0.61 & 0.61 & 0.61 & 2.44 & 0.61 & 7.12 \\
\hline D11 & $\mathrm{AG}=30 \mathrm{rpm}$ & 0.61 & 0.61 & 0.61 & 2.44 & 0.61 & 7.12 \\
\hline D12 & $\mathrm{AG}=40 \mathrm{rpm}$ & 0.61 & 0.61 & 0.61 & 2.44 & 0.61 & 7.12 \\
\hline D13 & $\mathrm{AG}=50 \mathrm{rpm}$ & 0.61 & 0.61 & 0.61 & 2.44 & 0.61 & 7.12 \\
\hline D14 & $\mathrm{AG}=60 \mathrm{rpm}$ & 0.61 & 0.61 & 0.61 & 2.44 & 0.61 & 7.12 \\
\hline D15 & $\mathrm{AG}=70 \mathrm{rpm}$ & 0.61 & 0.61 & 0.61 & 2.44 & 0.61 & 7.12 \\
\hline
\end{tabular}

N.B: T=Temperature; F/I = Feed/Inoculum; AG = Agitation speed

Anaerobic fermentation of the slurry (made up of mixed animal wastes with pineapple fruit wastes and content of chicken-gizzard) was carried out at feed/inoculum ratio of $(1: 1,1: 2,1: 3,2: 1$, and 3:1), temperature of $(25,30,40,50$ and $\left.60^{\circ} \mathrm{C}\right)$, and agitation speed of $(30,40,50,60$ and $70 \mathrm{rpm})$, respectively. Control experiment without agitation was also carried out. Biogas produced from the digester was collected directly into a gas bag and the biogas bag was then weighed by means of weighing scale. The mass of biogas produced was obtained from the difference between the initial mass of the biogas bag and the final mass of biogas bag plus biogas. The volume of biogas was obtained using Eq. (1):

$$
\text { Volume of Biogas }\left(\mathrm{dm}^{3}\right)=\frac{\text { Mass of biogas }(\mathrm{g})}{\text { Density of biogas }\left(\mathrm{g} / \mathrm{dm}^{3}\right)}
$$

Biogas yield (Y) was determined using Eq. (2) [51]:

$$
\boldsymbol{Y}\left(\mathrm{dm}^{3} / \mathrm{g}\right)=\frac{\text { Volume of biogas produced }\left(\mathrm{dm}^{3}\right)}{\text { Mass of feedstock (slurry)in biodigester (g) }}
$$

\subsection{Qualitative Gas Analysis}

The biogas was analyzed by means of gas chromatography using the thermal conductivity detector (TCD). The equipment model is Hp6890 with HP Chem Station and Rev. A09.01 (1206) software. The carrier gas was helium at $20 \mathrm{ml} / \mathrm{min}$ flow rate with the inlet temperature of $145^{\circ} \mathrm{C}$ while the inflow of the carrier gas was $26 \mathrm{ml} / \mathrm{min}$ in the column with dimensions and type $30 \mathrm{~m} \times 1 / 8 \mathrm{~mm} \times 0.85 \mu \mathrm{m}$ of and Heysep DB 100/120; Deerfield, Illinois respectively. The oven temperature was programmed at $140^{\circ} \mathrm{C}$ in $6 \mathrm{~min}$ and ramped at $50^{\circ} \mathrm{C} / \mathrm{min}$ to and maintained at $175^{\circ} \mathrm{C}$. 


\subsection{Kinetic Modelling of Biogas Generation}

The biogas production kinetics for the description and evaluation of methanogenesis was carried out by fitting the experimental data of biogas production to various kinetic equations. Cumulative biogas production rates of mixed animal wastes co-digested with pineapple fruit wastes) was simulated using logistic kinetic model, exponential rise to maximum and modified Gompertz kinetic models. Logistic kinetic equation is shown in Eq. (3) [52]:

$$
C=\frac{a}{1+b \exp (-k t)}
$$

Where, $\mathrm{C}$, cumulative biogas production $\left(\mathrm{dm}^{3} / \mathrm{gm}\right) ; k$, kinetic rate constant $\left(\right.$ day $\left.^{-1}\right) ; \mathrm{t}=$ hydraulic retention time, which is the time (i.e. days) the biodigester is incubated in the course of biogas production; $\mathrm{a}, \mathrm{b}$ are the constants. Exponential rise to maximum is presented in Eq. (4) [53 - 55]:

$$
C=A(1-\exp (-k t))
$$

Modified Gompertz kinetic model equation (Eq. (5)) is a modified form of the Gompertz equation which is commonly used to simulate the cumulative biogas production [48]. This model assumes that cumulative biogas production is a function of hydraulic retention time. The modified Gompertz equation can be presented as follows [52, 56, 57]:

$$
C=A \exp \left\{-\exp \left[\frac{r_{m} e}{A}(\lambda-t)+1\right]\right\}
$$

Where, $P$ is the cumulative of the specific biogas production $\left(\mathrm{dm}^{3} / \mathrm{gm}\right), \mathrm{A}$ is the biogas production potential $\left(\mathrm{dm}^{3} / \mathrm{gm}\right), \mathrm{r}_{\mathrm{m}}$ is the maximum biogas production rate $\left(\mathrm{dm}^{3} / \mathrm{gm} / \mathrm{day}\right), \lambda$ is the lag phase period or the minimum time required to produce biogas (day).

\subsection{Thermodynamic Consideration of Biogas Generation}

The thermodynamic parameters (mass fractions, specific gas constant, specific heats, ratio of the specific heats, internal energy, and enthalpy) of the biomethanization process were calculated using Eqs. (6) to (16) [58 - 60]. The mass fraction $\left(\mathrm{m}_{\mathrm{a}}\right)$ is estimated as given in Eq. (6):

$$
m_{a}=\frac{m_{i}}{m_{T}}
$$

The specific biogas constant (R) was estimated as given in Eq. (7):

$$
R=\sum_{i=1}^{n} R_{i}=\sum_{i=1}^{n} \frac{m_{i}}{m_{T}} \frac{R_{o}}{M_{i}}
$$

Specific heat at constant pressure $\left(\mathrm{C}_{\mathrm{p}}\right)$; specific heat at constant volume $\left(\mathrm{C}_{\mathrm{v}}\right)$; and the ratio of the specific heats $(\gamma)$, of biogas can be estimated using Eqs. (8) to (10), respectively.

$$
\begin{gathered}
C_{p}=\sum_{i=1}^{n} \frac{m_{i}}{m} C_{p i} \\
C_{v}=\sum_{i=1}^{n} \frac{m_{i}}{m} C_{v i} \\
\gamma=\frac{C_{p}}{C_{v}}
\end{gathered}
$$

Where for diatomic gases, $\mathrm{C}_{\mathrm{vi}}$ and $\mathrm{C}_{\mathrm{pi}}$ can be estimated using Eqs. (11) to (12), respectively. 


$$
C_{v i}=\frac{5}{2} R_{i}
$$

and

$$
C_{p i}=\frac{7}{2} R_{i}
$$

While for poly atomic gases, $\mathrm{C}_{\mathrm{vi}}$ and $\mathrm{C}_{\mathrm{pi}}$ can be estimated using Eqs. (13) to (14), respectively.

$$
C_{v i}=3 R_{i}
$$

and

$$
C_{p i}=4 R_{i}
$$

The specific internal energy $(u)$ and specific enthalpy $(h)$ of the biogas can be calculated using Eq. (15) and Eq. (16), respectively.

$$
\begin{aligned}
& u=C_{v} T \\
& h=C_{p} T
\end{aligned}
$$

Where, $R_{0}$ is the universal gas constant; $R_{i}$ is the specific gas constant of a component gas in the biogas mixture; $M_{i}$ is the mass of a component gas in the mixture; $\mathrm{C}_{\mathrm{vi}}$ and $\mathrm{C}_{\mathrm{pi}}$ are respectively the specific heat at constant volume and at constant pressure for component gas of the biogas mixture.

\section{RESULTS AND DISCUSSION}

\subsection{Effect of Operating Variables on Cumulative Biogas Yield and Biomethane Content}

Fig. (2) shows the effect of operating variables on the biomethanization of mixed animal wastes, co-digested with pineapple fruit waste and chicken rumen (inoculums).

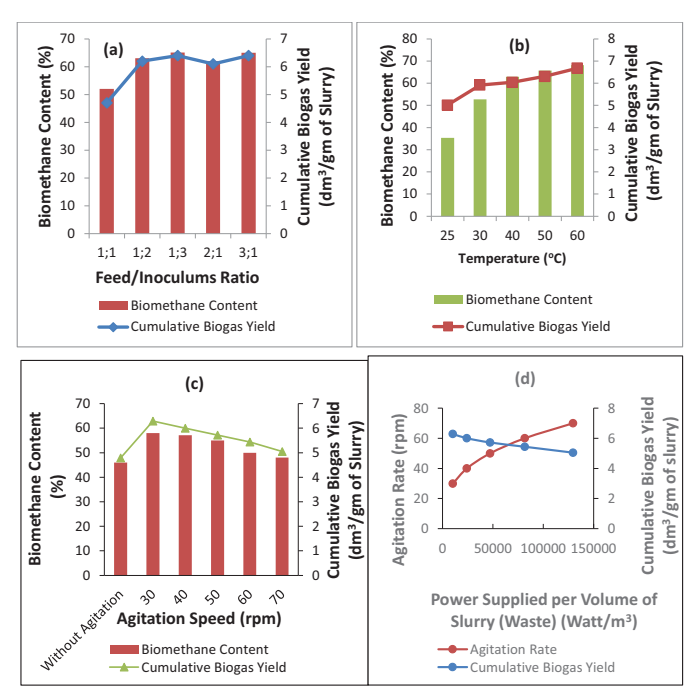

Fig. (2). Effect of process parameters on cumulative biogas yield and biomethane content (a) Effect of feed/inoculums ratio on cumulative biogas yield and biomethane content (b) Effect of temperature on cumulative biogas yield and biomethane content (c) Effect of agitation speed on cumulative biogas yield and biomethane content (d) Effect of agitation speed in relation to power supplied or consumed per volume of slurry (waste) on cumulative biogas yield. 
The cumulative biogas yield and its biomethane content generally increased with increase in the feed/inoculum ratio (Fig. 2A) where the inoculum fraction of the ratio was increased from $1: 1$ to $1: 2$ and 1:3, respectively and as well as where the feed (substrate) fraction of the ratio was increased from $1: 1$ to $2: 1$ and $3: 1$, respectively for biomethanization of mixed animal wastes co-digested with pineapple fruit wastes and inoculum (content of chicken-gizzard). That is, minimum cumulative biogas yield was obtained with the feed/inoculum ratio of $1: 1$ and the maximum with ratio $1: 3$ and $3: 1$, respectively.

Fig. (2B) shows the effect of temperature on the cumulative biogas yield and its biomethane content. It was observed that the rate of biomethanization increased with increase in temperature. Similar observations have been reported. Manik et al. [61] obtained a maximum gas production with enriched biomethane content of $62 \%$ at $40{ }^{\circ} \mathrm{C}$ while Usman et al. reported that temperature between 30 and $60{ }^{\circ} \mathrm{C}$ influence biogas generation from lignocellulosic material [11 - 61]. In this study, it was observed that the digester that was subjected to a temperature of $60^{\circ} \mathrm{C}$ had the highest biomethane yield of $66.8 \%$ with a cumulative biogas yield of $6.8149 \mathrm{dm}^{3} / \mathrm{gm}$ of slurry. This was relatively followed by that obtained at $50{ }^{\circ} \mathrm{C}\left(63.1 \% ; 6.5678 \mathrm{dm}^{3} / \mathrm{gm}\right.$ of slurry $), 40{ }^{\circ} \mathrm{C}\left(60.4 \% ; 6.2853 \mathrm{dm}^{3} /\right.$ gm of slurry $), 30{ }^{\circ} \mathrm{C}$ $\left(59.2 \% ; 5.2754 \mathrm{dm}^{3} /\right.$ gm of slurry), and $25^{\circ} \mathrm{C}\left(50.1 \% ; 3.5311 \mathrm{dm}^{3} / \mathrm{gm}\right.$ of slurry), respectively. The increase in biogas yield and biomethane content in the biogas is due to higher digestion rate and improved solids settling [62, 63]. According to Parker, there are two temperature ranges required $25-40^{\circ} \mathrm{C}$ for mesophilic and $45-60^{\circ} \mathrm{C}$ for thermophilic methane production; thus, the observation of higher biogas yield and biomethane content at 50 and $60{ }^{\circ} \mathrm{C}$ in this present study suggests that there are consortium of both mesophilic and thermophilic micro-organisms present in the substrates [64]. Methanogens are the bacteria that help decompose the substrate in the mesophilic temperature range, however, they become inactive at extremely high and low temperatures. Usman et al. have reported that stable reactor performance can be obtained at $55^{\circ} \mathrm{C}$ and $65^{\circ} \mathrm{C}$, respectively [11]. Adeniran et al. [51] obtained a biogas yield of 26.86 $\mathrm{ml} / \mathrm{kg}$ of slurry (equivalent to $0.00003 \mathrm{dm}^{3} / \mathrm{gm}$ ) in the anaerobic digestion of poultry wastes and cow dung at $37^{\circ} \mathrm{C}$ [51]. While Okuo et al. obtained a cumulative biogas yield of $487.5 \mathrm{~cm}^{3} / \mathrm{kg}$ (equivalent to $4.875 \times 10^{-4} \mathrm{dm}^{3} / \mathrm{gm}$ ), $467.5 \mathrm{~cm}^{3} / \mathrm{kg}$ (equivalent to $4.675 \times 10^{-4} \mathrm{dm}^{3} / \mathrm{gm}$ ) and $457.5 \mathrm{~cm}^{3} / \mathrm{kg}$ (equivalent to $4.575 \times 10^{-4} \mathrm{dm}^{3} / \mathrm{gm}$ ) in the anaerobic digestion of the mixture of cattle manure, swine manure and poultry manure in the ratio $4: 1: 3,2: 1: 1$ and $4: 3: 1$, respectively, at temperature range of

The effect of agitation speed on the cumulative biogas yield and its biomethane content is shown in Fig. (2C). It was observed that the rate of biomethanization of mixed animal wastes co-digested with pineapple fruit waste and inoculums decreased with increase in agitation speed from 30 to $70 \mathrm{rpm}$. The digester subjected to $30 \mathrm{rpm}$ agitation speed had the highest biogas yield $\left(6.2853 \mathrm{dm}^{3} / \mathrm{gm}\right)$ with biomethane content $(58 \%)$ and relatively followed by that of

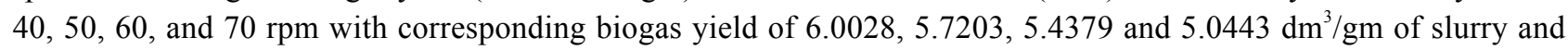
biomethane content of $57.1 \%, 55 \%, 50 \%$ and $48 \%$, respectively. The power supplied by agitation was estimated using Eqs. (17) and (18) and the result is as shown in Fig. (2D).

$$
\text { Power Supplied Per Volume of Slurry }=\frac{N_{p} \times \rho \times N^{3} \times D^{5}}{V_{s}}
$$

Where $\mathrm{N}_{\mathrm{p}}$ is power number and is a function of the Reynolds number $\left(\mathrm{N}_{\mathrm{Re}}\right)$ [i.e. $\mathrm{N}_{\mathrm{p}}=\mathrm{f}\left(\mathrm{N}_{\mathrm{Re}}\right)$ ]

$$
N_{\mathrm{Re}}=\frac{\rho \times N \times D^{2}}{\mu}
$$

$\rho$ is density of fermentation slurry, $N$ is rotational speed of impeller, $\mu$ is viscosity of fermentation slurry, $D$ is impeller diameter and $V_{s}$ is volume of fermentation slurry, respectively.

Fig. (2D) shows that as the agitation speed increases so does the power supplied or consumed per volume of slurry/waste also increases and the cumulative biogas yield relatively decreased. Nevertheless, the cumulative biogas yield with its biomethane content obtained from the biomethanization process with agitation ( $30-70 \mathrm{rpm})$ was found to be relatively higher than the cumulative biogas yield of $4.7882 \mathrm{dm}^{3} / \mathrm{gm}$ of slurry with biomethane content of $46 \%$ that was respectively obtained without agitation. Thus, with agitation speed of $30-70 \mathrm{rpm}$, increase in the cumulative biogas yield ranged from 5.3 to $31.3 \%$ and its biomethane content from 4.3 to $26.1 \%$ above the cumulative biogas yield and biomethane content obtained without agitation. According to Muthanna et al., biogas production will increase by $15 \%$ for mixed digester compared to an unmixed one [65]. Karima et al. in their study have observed an increase of 10 
to $30 \%$ in biogas production with agitation [24]. Kaparaju et al. have also reported that an increase of 7\% in biogas yield was attained with intermittent mixing as compared to continuous mixing [22]. Thus, a moderately agitated digester is required for optimal gas production.

\subsection{Effect of Operating Variables on Start-Up Time of Biogas/Biomethane Generation}

Fig. (3) shows the effect of operating variables on the start-up time of the biomethanization process of cattle manure, pig manure and chicken manure mixture co-digested with pineapple fruit waste and content of chicken-gizzard (inoculums).

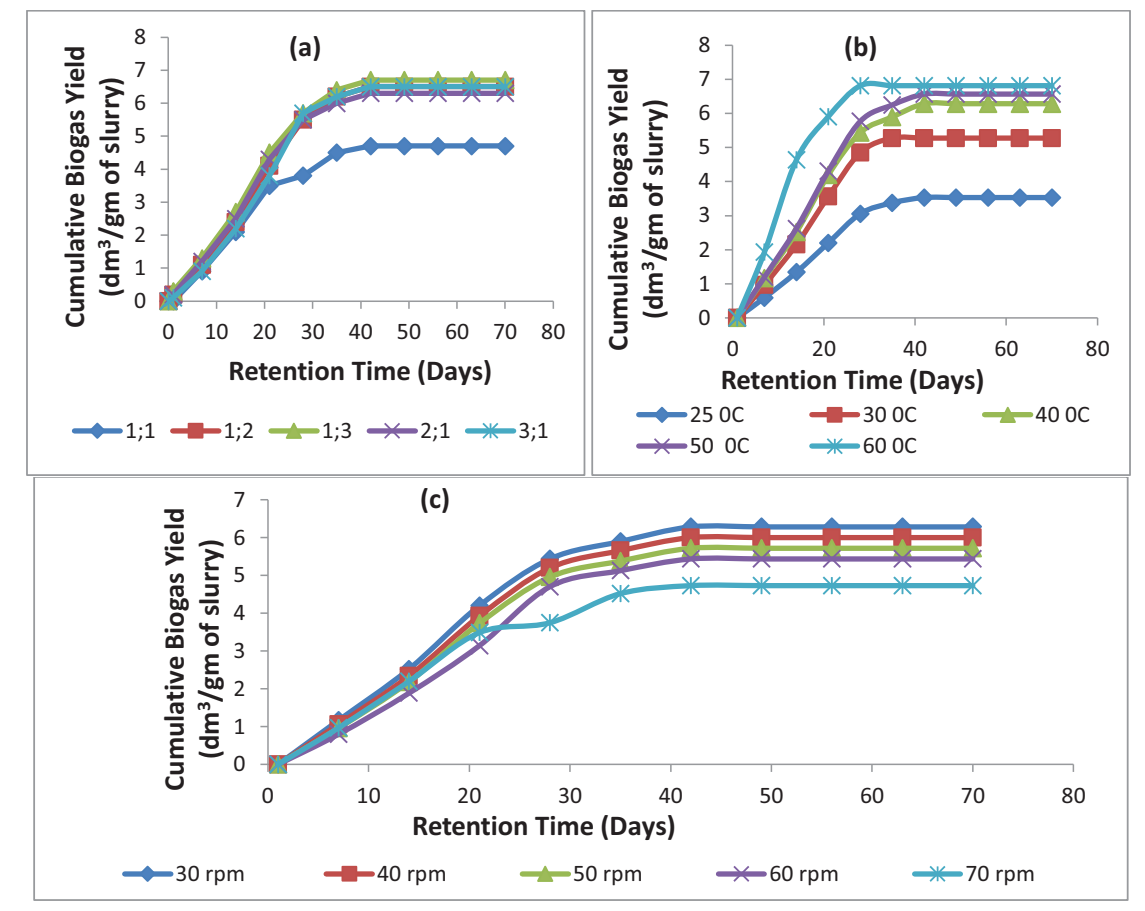

Fig. (3). Effect of process parameters on biomethanization start-up time: (a) Effect of feed/inoculum ratio on start-up time (b) Effect of temperature on start-up time (c) Effect of agitation speed on start-up time.

The biomethanization process started with the generation of biogas/biomethane on day 5 without the use of inoculum while it started on day 1 with the production of biogas/biomethane for the use of feed/inoculum ratio of $1: 1$, $1: 2,1: 3,2: 1$ and $3: 1$ and the biogas production increased until it reached its peak on day $42\left(6^{\text {th }}\right.$ week) and remained constant till day $70\left(10^{\text {th }}\right.$ week) (Fig. 3A).

The effect of temperature on start-up time is shown in Fig. (3B). The biomethanization process started with biogas/biomethane production on day 5 for temperature of $25^{\circ} \mathrm{C}$ (ambient temperature) while biogas/biomethane generation started on day 1 for temperature of $30{ }^{\circ} \mathrm{C}, 40{ }^{\circ} \mathrm{C}, 50{ }^{\circ} \mathrm{C}$, and $60{ }^{\circ} \mathrm{C}$, respectively. The set up at $25{ }^{\circ} \mathrm{C}$ displayed the least production rate with peak biogas accumulation yield obtained on day $49\left(7^{\text {th }}\right.$ week $)$ and remained constant till day 70. It is observed that the biodigester set up at $60{ }^{\circ} \mathrm{C}$ has the fastest production rate as it attains peak performance on day 28 ( $4^{\text {th }}$ week $)$ and remained constant till day $70\left(10^{\text {th }}\right.$ week $)$. This is relatively followed by biodigester set up at 50 ${ }^{\circ} \mathrm{C}, 40{ }^{\circ} \mathrm{C}$ and $30{ }^{\circ} \mathrm{C}$, each with peak biogas accumulation yield obtained on day 35 ( $5^{\text {th }}$ week) and remained constant till day $70\left(10^{\text {th }}\right.$ week). A similar observation has been reported by Manjula et al. stating that maximum biogas production rate occurred at about 25 days for all the three cases of temperature $\left(55^{\circ} \mathrm{C}, 45^{\circ} \mathrm{C}\right.$ and $\left.35{ }^{\circ} \mathrm{C}\right)$ that was investigated [12]. From this study, it is obvious that maximum biogas production was enhanced by the thermophilic methanogenic bacteria at $60{ }^{\circ} \mathrm{C}, 50{ }^{\circ} \mathrm{C}$ and $40{ }^{\circ} \mathrm{C}$ while at $25{ }^{\circ} \mathrm{C}$; the action of the methanogenic bacteria was less effective.

Fig. (3C) shows the effect of agitation speed on start-up time. The biomethanization process without agitation started biogas/biomethane generation on day 5 while it started biogas/biomethane production on day 1 for agitation speed of $30 \mathrm{rpm}, 40 \mathrm{rpm}, 50 \mathrm{rpm}, 60 \mathrm{rpm}$, and $70 \mathrm{rpm}$, respectively. It is observed that the biodigester set up at $30 \mathrm{rpm}$ has the fastest production rate as it attained peak performance on day 35 ( $5^{\text {th }}$ week) and this remained constant till day 
$70\left(10^{\text {th }}\right.$ week $)$. While the digester set up at $40 \mathrm{rpm}$ has the second fastest production rate with peak accumulation yield on day $35\left(5^{\text {th }}\right.$ week $)$ and remained constant till day 70 . This is relatively followed by the biodigester set up at $50 \mathrm{rpm}$, $60 \mathrm{rpm}$ and $70 \mathrm{rpm}$ which had their biogas peak accumulation yield on day $49\left(7^{\text {th }}\right.$ week, $), 56\left(8^{\text {th }}\right.$ week $)$ and $49\left(7^{\text {th }}\right.$ week), respectively, and remained constant till day 70 .

\subsection{Kinetics of Mixed Animal Wastes Biomethanization Process}

The kinetics of biogas production from biomethanization of mixed animal wastes co-digested with pineapple fruit wastes and inoculum (chicken rumen) was carried out by fitting the biogas production experimental data obtained at different operating parameters of feed/inoculums ratio, temperature and agitation speed to three forms of kinetic model equations which are logistic kinetic model, exponential rise to maximum and modified Gompertz kinetic model using the non-linear regression tool of MATLAB 7.0 software package and the estimated kinetic parameters and coefficient of determinations $\left(\mathrm{R}^{2}\right)$ obtained are presented in Tables $\mathbf{3}$ to $\mathbf{5}$ respectively.

Table 3. Value of model constants and coefficient of determination $\left(R^{2}\right)$ obtained from kinetic models fitted to cumulative biogas production data of biomethanization of mixed animal wastes co-digested with pineapple fruit wastes and chicken rumen at different feed/inoculums ratio.

\begin{tabular}{|c|c|c|c|c|c|c|}
\hline \multirow[t]{2}{*}{ Models } & \multirow[t]{2}{*}{ Constant Variables } & \multicolumn{5}{|c|}{ Feed/Inoculum Ratio } \\
\hline & & $1: 1$ & $1: 2$ & $1: 3$ & $2: 1$ & $3: 1$ \\
\hline \multirow[t]{4}{*}{ Logistic Kinetic } & $a$ & 3.858 & 5.216 & 5.396 & 5.181 & 5.205 \\
\hline & $b$ & -3.858 & -5.216 & -5.396 & -5.181 & -5.205 \\
\hline & $k\left(\right.$ day $\left.^{-1}\right)$ & 10.26 & 9.814 & 9.74 & 9.827 & 9.818 \\
\hline & $\mathrm{R}^{2}$ & 0.4665 & 0.4155 & 0.4427 & 0.4443 & 0.3884 \\
\hline \multirow[t]{3}{*}{ Exponential Rise to Maximum } & $A\left(\mathrm{dm}^{3} / \mathrm{gm}\right)$ & 5.156 & 7.292 & 7.556 & 7.063 & 7.385 \\
\hline & $k\left(\right.$ day $\left.^{-1}\right)$ & 0.04223 & 0.04492 & 0.04731 & 0.03857 & 0.04443 \\
\hline & $R^{2}$ & 0.9767 & 0.959 & 0.9714 & 0.9702 & 0.9517 \\
\hline \multirow[t]{4}{*}{ Modified Gompertz Kinetic } & $A\left(\mathrm{dm}^{3} / \mathrm{gm}\right)$ & 4.798 & 6.161 & 6.844 & 6.05 & 6.233 \\
\hline & $r_{m}\left(\mathrm{dm}^{3} / \mathrm{gm} /\right.$ day $)$ & 0.02682 & 0.9342 & 27.5 & 0.02417 & 0.03591 \\
\hline & $\lambda$ (day) & 1.485 & 0.9813 & 0.5067 & 0.5011 & \begin{tabular}{|l|l|}
0.4918 \\
\end{tabular} \\
\hline & $R^{2}$ & \begin{tabular}{|l|}
0.9937 \\
\end{tabular} & 0.964 & \begin{tabular}{|l|}
0.9936 \\
\end{tabular} & 0.9708 & 0.9568 \\
\hline
\end{tabular}

Table 4. Value of model constants and coefficient of determination $\left(R^{2}\right)$ obtained from kinetic models fitted to cumulative biogas production data of biomethanization of mixed animal wastes co-digested with pineapple fruit waste and chicken rumen at different temperature.

\begin{tabular}{|c|c|c|c|c|c|c|}
\hline \multirow{2}{*}{ Models } & Constant Variables & \multicolumn{3}{|c|}{ Temperature $\left({ }^{\circ} \mathbf{C}\right)$} \\
\cline { 2 - 5 } & & $\mathbf{2 5}$ & $\mathbf{3 0}$ & $\mathbf{4 0}$ & $\mathbf{5 0}$ & $\mathbf{6 0}$ \\
\hline Logistic Model & $a$ & 2.823 & 4.506 & 5.065 & 5.301 & 5.572 \\
\cline { 2 - 6 } & $b$ & -2.823 & -4.506 & -5.065 & -5.301 & -5.572 \\
\cline { 2 - 6 } & $k\left(\mathrm{day}^{-1}\right)$ & 10.48 & 10.07 & 9.872 & 9.779 & 9.665 \\
\cline { 2 - 6 } & $R^{2}$ & 0.4101 & 0.4135 & 0.4317 & 0.4282 & 0.4458 \\
\hline Exponential Rise to Maximum & $A\left(\mathrm{dm}^{3} / \mathrm{gm}\right)$ & 3.996 & 6.387 & 7.002 & 7.331 & 7.519 \\
\cline { 2 - 6 } & $k\left(\mathrm{day}^{-1}\right)$ & 0.04087 & 0.04069 & 0.04333 & 0.04334 & 0.04628 \\
\cline { 2 - 6 } & $R^{2}$ & 0.9598 & 0.964 & 0.9676 & 0.9643 & 0.9652 \\
\hline Modified Gompartz Kinetic & $A\left(\mathrm{dm}^{3} / \mathrm{gm}\right)$ & 3.589 & 5.39 & 5.978 & 6.299 & 6.88 \\
\cline { 2 - 6 } & $r_{m}\left(\mathrm{dm}^{3} / \mathrm{gm} / \mathrm{day}\right)$ & 47.02 & 73.54 & 164.6 & 203.5 & 205.7 \\
\cline { 2 - 6 } & $\lambda(\mathrm{day})$ & 0.5573 & 0.4994 & 0.4832 & 0.47 & 0.4412 \\
\cline { 2 - 6 } & $R^{2}$ & 0.9837 & 0.9692 & 0.9713 & 0.9722 & 0.9819 \\
\hline
\end{tabular}


Table 5. Value of model constants and coefficient of determination $\left(R^{2}\right)$ obtained from kinetic models fitted to cumulative biogas production data of biomethanization of mixed animal wastes co-digested with pineapple fruit waste and chicken rumen at different agitation speed

\begin{tabular}{|c|c|c|c|c|c|c|}
\hline \multirow[t]{2}{*}{ Models } & \multirow[t]{2}{*}{ Constant Variables } & \multicolumn{5}{|c|}{ Agitation (rpm) } \\
\hline & & 30 & 40 & 50 & 60 & 70 \\
\hline \multirow[t]{4}{*}{ Logistic Kinetic } & $a$ & 5.065 & 4.819 & 4.582 & 4.285 & 3.858 \\
\hline & $b$ & -5.065 & -4.819 & -4.582 & -4.285 & -3.858 \\
\hline & $k\left(\right.$ day $\left.^{-1}\right)$ & 9.872 & 9.963 & 10.05 & 10.14 & 10.26 \\
\hline & $R^{2}$ & 0.4317 & 0.4218 & 0.4155 & 0.3842 & 0.4665 \\
\hline \multirow[t]{3}{*}{ Exponential Rise to Maximum } & $A\left(\mathrm{dm}^{3} / \mathrm{gm}\right)$ & 7.002 & 6.732 & 6.437 & 6.293 & 5.156 \\
\hline & $k\left(\right.$ day $\left.^{-1}\right)$ & 0.04731 & 0.04333 & 0.04222 & 0.04167 & 0.03748 \\
\hline & $R^{2}$ & 0.9767 & 0.9676 & 0.9644 & 0.9621 & 0.9519 \\
\hline \multirow[t]{4}{*}{ Modified Gompartz Kinetic } & $A\left(\mathrm{dm}^{3} / \mathrm{gm}\right)$ & 5.978 & 5.724 & 5.451 & 5.12 & 4.798 \\
\hline & $r_{m}\left(\mathrm{dm}^{3} / \mathrm{gm} /\right.$ day $)$ & 152.7 & 60.58 & 30.95 & 16.9 & 0.9342 \\
\hline & $\lambda$ (day) & 0.4641 & 0.4755 & 0.4832 & \begin{tabular}{|l|}
0.4843 \\
\end{tabular} & 1.485 \\
\hline & $R^{2}$ & 0.9713 & \begin{tabular}{|l|}
0.9699 \\
\end{tabular} & \begin{tabular}{|l|}
0.9682 \\
\end{tabular} & \begin{tabular}{|l|}
0.9524 \\
\end{tabular} & \begin{tabular}{|l|}
0.9937 \\
\end{tabular} \\
\hline
\end{tabular}

As presented in Tables (3 to 5), the $R^{2}$ is relatively higher for modified Gompertz kinetic model (0.9568-0.9937); (0.9713-0.9837) and (0.9524-0.9937) as well as for exponential rise to maximum (0.959-0.9767); (0.9598-0.9676) and (0.9519-0.9767) as compared to that of the logistic kinetic model (0.3884-0.4665); (0.4101-0.4458) and (0.3842-0.4665) at different feed/inoculums ratio, temperature and agitation speed, respectively. The higher value of $R^{2}$ above 0.90 for both modified Gompertz and exponential rise to maximum kinetic models indicates that both models fitted very well to the experimental biomethanization data and thus can be used to simulate biogas production from biomethanization of mixed animal wastes co-digested with pineapple fruit wastes at different condition of feed/inoculums ratio, temperature and agitation, respectively. As it could be seen in Tables (3 to 5), the kinetic constants of exponential rise to maximum, i.e. the first order kinetic constant $(k)$ and the cumulative biogas production $(A)$ increased with increase in the feed/inoculum ratio where the inoculum fraction of the ratio was increased $(1: 1,1: 2$, $1: 3)$ and where the feed (substrate) fraction of the ratio was increased (1:1, 2:1, 3:1), respectively (Table 3).

In addition, these constants i.e. the first order kinetic constant $(k)$ and the cumulative biogas production $(A)$ generally increased with increase in temperature and decreased with increase in agitation speed Tables (4 and 5). Similarly, for modified Gompertz equation, biogas production potential $(A)$ and biogas production rate $\left(r_{m}\right)$ generally increased with increase in the feed/inoculum ratio where the inoculum fraction of the ratio was increased $(1: 1,1: 2,1: 3)$ and where the feed (substrate) fraction of the ratio was increased $(1: 1,2: 1,3: 1)$ respectively, while the lag phase $(\lambda)$ decreased with increase in the feed/inoculum ratio where the inoculum fraction of the ratio was increased $(1: 1,1: 2,1: 3)$ and where the feed (substrate) fraction of the ratio was increased (1:1, 2:1, 3:1), respectively (Table 3).

Furthermore, the biogas production potential $(A)$ and biogas production rate $\left(r_{m}\right)$ also generally increased with increase in temperature and decreased with increase in agitation speed, respectively while the lag phase ( $\lambda$ generally decreased with increase in temperature and increased with increase in agitation speed, respectively (Tables 4 and $\mathbf{5}$ ). In logistic kinetic model, the kinetic rate constant was found to increase with increase in feed/inoculums ratio up to 2:1 and decreased at feed/inoculums ratio 3:1 (Table 3). Also, the logistic kinetic rate constant decreased with increase in temperature as well as increased with increase in agitation speed (Tables $\mathbf{4}$ and $\mathbf{5}$ ).

\subsection{Estimation of Thermodynamic Parameters and Activation Energy}

The chromatographic analysis of biogas obtained from the biomethanization of cattle manure, pig manure and chicken manure mixture co-digested with pineapple fruit waste and content of chicken-gizzard at different temperature of 25, 30, 40, 50 and $60{ }^{\circ} \mathrm{C}$ indicated that the gas constituents are $\mathrm{CH}_{4}, \mathrm{CO}_{2}, \mathrm{H}_{2} \mathrm{~S}, \mathrm{CO}$ and $\mathrm{NH}_{3}$. Using Eq. (6) to Eq. (16), the estimated mass fractions of the biogas constituents, gas constant, specific heat capacities and ratio of the specific heats of the biogas produced at different temperature of $25,30,40,50$ and $60{ }^{\circ} \mathrm{C}$, from the biomethanization of cattle manure, pig manure and chicken manure mixture co-digested with pineapple fruit waste and content of chickengizzard are presented in Table 6. 
Table 6. The percentage composition, mass fraction, gas constant and specific heat capacities of biogas produced from biomethanization of mixed animal waste co-digested with pineapple fruit waste and chicken rumen

\begin{tabular}{|c|c|c|c|c|c|c|c|}
\hline Temperature & Constituent & Composition \% & $\begin{array}{c}\text { Mass in } \\
\text { Mixture (kg) }\end{array}$ & Mass fraction & $R_{i}(\mathrm{~kJ} / \mathbf{k g K})$ & $C_{V i}(\mathrm{~kJ} / \mathbf{k g K})$ & $\begin{array}{c}C_{P i} \\
(\mathrm{~kJ} / \mathrm{kgK})\end{array}$ \\
\hline \multirow{6}{*}{$25^{\circ} \mathrm{C}$} & $\mathrm{CH}_{4}$ & 50.277 & 8.044 & 0.2743 & 0.1426 & 0.4276 & 0.5702 \\
\hline & $\mathrm{CO}_{2}$ & 46.293 & 20.369 & 0.6947 & 0.1313 & 0.3937 & 0.5250 \\
\hline & $\mathrm{H}_{2} \mathrm{~S}$ & 1.165 & 0.396 & 0.0135 & 0.0033 & 0.0099 & 0.0132 \\
\hline & $\mathrm{CO}$ & 1.159 & 0.324 & 0.0111 & 0.0033 & 0.0080 & 0.0115 \\
\hline & $\mathrm{NH}_{3}$ & 1.106 & 0.188 & 0.0064 & 0.0031 & 0.0094 & 0.0125 \\
\hline & Total & 100 & 29.321 & 1 & 0.2836 & 0.8489 & 1.1324 \\
\hline \multirow{6}{*}{$30{ }^{\circ} \mathrm{C}$} & $\mathrm{CH}_{4}$ & 59.277 & 9.484 & 0.3470 & 0.1803 & 0.5409 & 0.7213 \\
\hline & $\mathrm{CO}_{2}$ & 40.293 & 17.729 & 0.6487 & 0.1226 & 0.3677 & 0.4903 \\
\hline & $\mathrm{H}_{2} \mathrm{~S}$ & 0.165 & 0.056 & 0.0021 & 0.0005 & 0.0015 & 0.0020 \\
\hline & $\mathrm{CO}$ & 0.159 & 0.044 & 0.0016 & 0.0005 & 0.0012 & 0.0017 \\
\hline & $\mathrm{NH}_{3}$ & 0.106 & 0.018 & 0.0007 & 0.0003 & 0.0010 & 0.0013 \\
\hline & Total & 100 & 27.331 & 1 & 0.3042 & 0.9123 & 1.2166 \\
\hline \multirow{6}{*}{$40{ }^{\circ} \mathrm{C}$} & $\mathrm{CH}_{4}$ & 60.435 & 9.670 & 0.3617 & 0.1879 & 0.5638 & 0.7517 \\
\hline & $\mathrm{CO}_{2}$ & 37.469 & 16.487 & 0.6166 & 0.1165 & 0.3495 & 0.4661 \\
\hline & $\mathrm{H}_{2} \mathrm{~S}$ & 0.949 & 0.323 & 0.0121 & 0.0030 & 0.0089 & 0.0118 \\
\hline & $\mathrm{CO}$ & 0.574 & 0.161 & 0.0060 & 0.0018 & 0.0045 & 0.0062 \\
\hline & $\mathrm{NH}_{3}$ & 0.573 & 0.097 & 0.0036 & 0.0018 & 0.0053 & 0.0071 \\
\hline & Total & 100 & 26.738 & 1 & 0.3110 & 0.9320 & 1.2429 \\
\hline \multirow{12}{*}{$\begin{array}{l}50^{\circ} \mathrm{C} \\
60^{\circ} \mathrm{C}\end{array}$} & $\mathrm{CH}_{4}$ & 63.146 & 10.103 & 0.3903 & 0.2028 & 0.6084 & 0.8112 \\
\hline & $\mathrm{CO}_{2}$ & 34.495 & 15.178 & 0.5863 & 0.1108 & 0.3324 & 0.4432 \\
\hline & $\mathrm{H}_{2} \mathrm{~S}$ & 0.719 & 0.245 & 0.0094 & 0.0023 & 0.0069 & 0.0092 \\
\hline & $\mathrm{CO}$ & 0.739 & 0.207 & 0.0080 & 0.0024 & 0.0059 & 0.0083 \\
\hline & $\mathrm{NH}_{3}$ & 0.901 & 0.153 & 0.0059 & 0.0029 & 0.0087 & 0.0116 \\
\hline & Total & 100 & 25.886 & 1 & $\begin{array}{l}0.3212 \\
\end{array}$ & $\begin{array}{l}0.9623 \\
\end{array}$ & 1.2835 \\
\hline & $\mathrm{CH}_{4}$ & 66.817 & 10.691 & 0.4313 & 0.2241 & 0.6723 & 0.8964 \\
\hline & $\mathrm{CO}_{2}$ & 30.380 & 13.367 & 0.5392 & 0.1019 & 0.3057 & 0.4076 \\
\hline & $\mathrm{H}_{2} \mathrm{~S}$ & 0.928 & 0.315 & 0.0127 & 0.0031 & 0.0093 & 0.0124 \\
\hline & $\mathrm{CO}$ & 0.884 & 0.248 & 0.0100 & 0.0030 & 0.0074 & 0.0104 \\
\hline & $\mathrm{NH}_{3}$ & 0.991 & 0.168 & 0.0068 & 0.0033 & 0.0100 & 0.0133 \\
\hline & Total & 100 & 24.789 & 1 & 0.3354 & 1.0047 & 1.3401 \\
\hline
\end{tabular}

$R_{i}=$ gas constant; $C_{V i}=$ specific heat capacity at constant volume; $C_{P i}=$ specific heat capacity at constant pressure

As presented in Table (6), it could be seen that the $\mathrm{CH}_{4}$ has the highest molar composition at various temperatures which is an indication of the high quality of the biogas produced. It also has the highest specific heat at constant volume and pressure at various temperatures. These specific heats increased with increasing temperature which is a confirmation of their temperature dependency. A similar observation has been reported for biogas generation from cattle dung by Yaru et al. [59]. The other components of biogas produced in their decreasing order of molar composition are $\mathrm{CO}_{2}, \mathrm{H}_{2} \mathrm{~S}, \mathrm{CO}$ and $\mathrm{NH}_{3}$. The heat capacities of these components followed the same trend as $\mathrm{CH}_{4}$. An important constant in the estimation of heat capacities of gases is the ratio of specific heat at constant pressure to constant volume $(\gamma)$. All the components of the biogas produced except for $\mathrm{CO}$ are polyatomic gases with the value of $\gamma$ being 1.33 (for polyatomic gas) while $\mathrm{CO}$ has 1.44 (for diatomic gas). The value of $\gamma$ for the biogas is also 1.33 which is a reflection that the biogas is predominantly composed of polyatomic gases and this is in agreement with the observation and report of Yaru et al. and Eastop and McConkey [59, 66].

The specific internal energy $(u)$ and enthalpy $(h)$ of biogas and biomethane content obtained from biomethanization of cattle manure, pig manure and chicken manure mixture co-digested with pineapple fruit waste and content of chicken-gizzard at different temperature was calculated based on Eq. (15) and Eq. (16), respectively, and the results are presented in Fig. (4A). Fig. (4A) shows the plot of specific internal energy of biogas and specific internal energy of biomethane content against temperature $(\mathrm{K})$. 


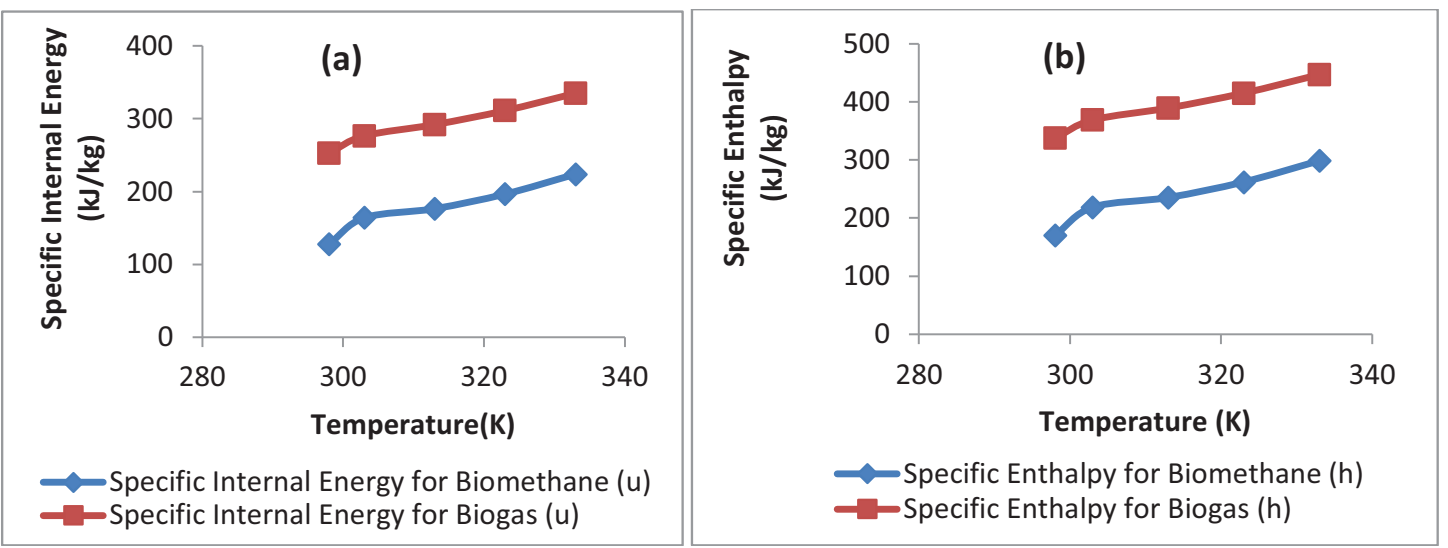

Fig. (4). (a) Specific internal energy of biomethane and biogas (b) Specific enthalpy of biomethane and biogas from biomethanization of mixed animal wastes co-digested with pineapple fruit waste and chicken rumen at different temperature.

As seen in Fig. (4A), the value of specific internal energy of biogas and specific internal energy content of biomethane respectively increased as temperature increased. A similar observation has been reported [59]. The maximum specific internal energy of biomethane $\left(\mathrm{CH}_{4}\right)$ content obtained is $223.8712 \mathrm{~kJ} / \mathrm{kg}$ and the lowest, 127.4457 $\mathrm{kJ} / \mathrm{kg}$ while the maximum specific internal energy of biogas is $335.0503 \mathrm{~kJ} / \mathrm{kg}$ and the lowest being $252.9978 \mathrm{~kJ} / \mathrm{kg}$. Yaru et al. obtained $279.48923 \mathrm{~kJ} / \mathrm{kg}$ and $273.95479 \mathrm{~kJ} / \mathrm{kg}$ as the maximum specific internal energy and the lowest specific internal energy of biogas from cattle dung, respectively [59].

Fig. (4B) shows the plot of specific enthalpy of biogas and biomethane content against temperature (K). As shown in Fig. (4B), the values of specific enthalpy of biogas and specific enthalpy of biomethane content respectively increased with increased temperature. The maximum specific enthalpy of biomethane $\left(\mathrm{CH}_{4}\right)$ content is $298.4948 \mathrm{~kJ} / \mathrm{kg}$ and the minimum is $169.9274 \mathrm{~kJ} / \mathrm{kg}$ while the highest specific enthalpy of biogas is $446.7335 \mathrm{~kJ} / \mathrm{kg}$ and the lowest being $337.4935 \mathrm{~kJ} / \mathrm{kg}$. Yaru et al. obtained $375 \mathrm{~kJ} / \mathrm{kg}$ as the maximum specific enthalpy of biogas obtained from cattle dung anaerobic digestion [59]. In comparison with the values obtained by Yaru et al., this study revealed that the biogas produced from the biomethanization of cattle manure, pig manure and chicken manure mixture in co-digestion with waste of pineapple fruit and content of chicken-gizzard possess higher values of specific internal energy and specific enthalpy than biogas generated from mono-anaerobic digestion of cattle manure (or substrate) [59].

In order to study the feasibility of the biomethanization process, thermodynamic parameters such as changes in standard Gibb's free energy $\left(\Delta G^{0}\right)$, standard enthalpy $\left(\Delta H^{0}\right)$, and standard entropy $\left(\Delta S^{0}\right)$. can be estimated. The standard Gibb's free energy $\left(\Delta G^{0}\right)$ was calculated according to Eyring-Polanyi equation (Eq. (19)) [67]:

$$
\begin{gathered}
k=\frac{k_{b} T}{h} \exp \left(-\frac{\Delta G}{R T}\right) \\
\Delta G^{o}=\Delta H^{o}-T \Delta S^{o}
\end{gathered}
$$

Taking natural logarithm of Eq. (19) and substituting Eq. (20) into Eq. (19) gives:

$$
\ln \left(\frac{k}{T}\right)=-\left(\frac{\Delta H^{o}}{R T}\right)+\left[\ln \kappa+\ln \left(\frac{k_{b}}{h}\right)+\frac{\Delta S^{o}}{R}\right]
$$

Where $\mathrm{k}$ is the rate constant $\left(\mathrm{s}^{-1}\right), \mathrm{T}$ is the absolute temperature $(\mathrm{K}), \mathrm{R}, \mathrm{k}_{\mathrm{b}}$ and $\mathrm{h}$ are the universal gas $\left(8.314 \mathrm{~J} \mathrm{~mol}^{-1}\right.$ $\left.\mathrm{K}^{-1}\right)$, Boltzmann $\left(1.38 \times 10^{-23} \mathrm{~J} / \mathrm{K}\right)$ and Planck's $\left(6.63 \times 10^{-34} \mathrm{~J} \mathrm{~s}\right)$ constants, respectively. The transmission coefficient $\kappa$ is often taken as unity. From the plot of $\ln (\mathrm{k} / \mathrm{T}) v s .1 / \mathrm{T}$ (Fig. 5), 


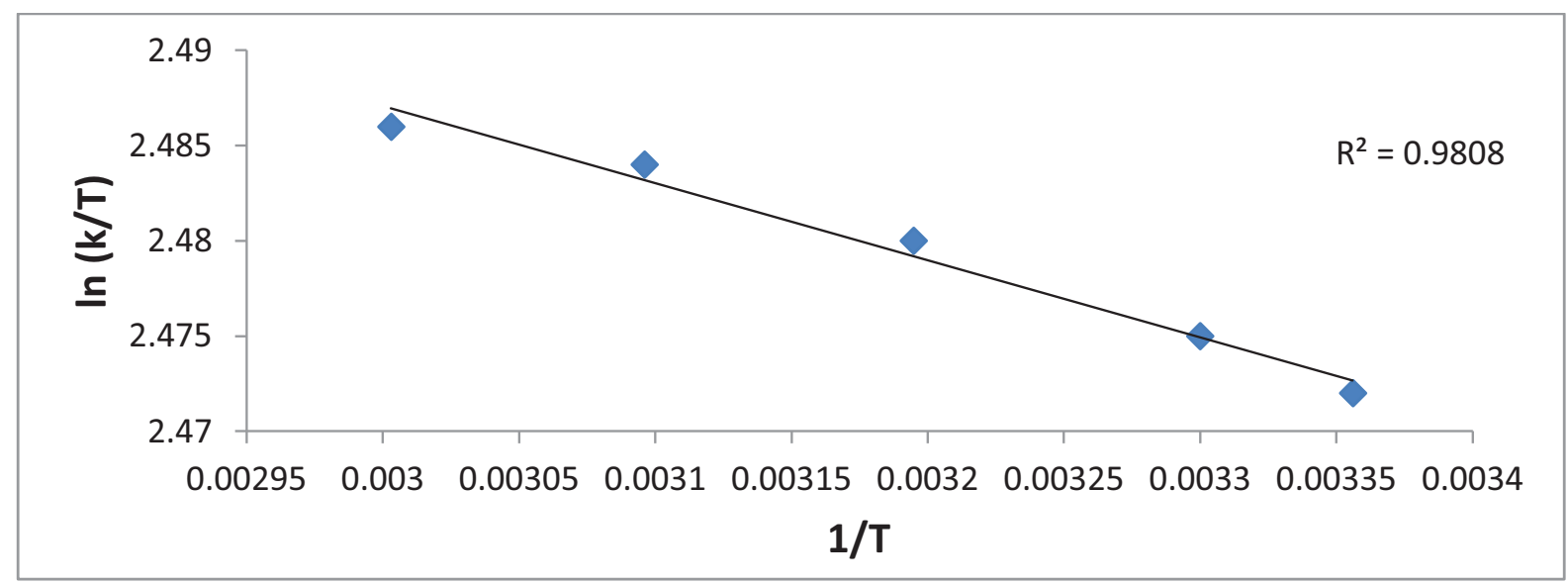

Fig. (5). plot of $\ln \mathrm{k} / \mathrm{T}$ against 1/T for estimating Erying -Polanyi Parameters.

$\Delta H^{0}$ and $\Delta S^{0}$ were obtained from values of the slope and intercept, respectively, and thus $\Delta G^{0}$ was obtained using Eq. (20). The results are presented in (Table 7).

Table 7. The thermodynamic parameters for biomethanization.

\begin{tabular}{|c|c|c|c|}
\hline $\begin{array}{c}\text { Temperature } \\
\text { (K) }\end{array}$ & $\Delta H^{\theta}(\mathrm{kJ} / \mathrm{mol})$ & $\begin{array}{c}\Delta S^{0} \\
(\mathrm{~J} / \mathrm{mol} \text {. K) }\end{array}$ & $\begin{array}{c}\Delta G^{0} \\
(\mathrm{~J} / \mathbf{m o l})\end{array}$ \\
\hline $\begin{array}{l}298 \\
303 \\
313 \\
323 \\
333\end{array}$ & 336.43 & 15.58 & $\begin{array}{l}-4306.41 \\
-4720.74 . \\
-4876.54 \\
-5032.34 \\
-5188.14\end{array}$ \\
\hline
\end{tabular}

As presented in Table 7, the positive value of $\Delta H^{0}$ indicates that the biomethanization process is endothermic in nature. The positive value of $\Delta S^{0}$ revealed that the biomethanization process is entropy driven. The negative value of $H^{0}$ $\Delta G^{0}$ depicts that the biomethanization reaction is feasible and spontaneous. The positive value of $\Delta H^{0}$ in this present study implies that the biomethanization process made use of heat energy from the surrounding environment and also suggests that acetoclastic methanogens may not be the predominant microorganisms in the biodigester as these methanogens function optimally at mesophilic temperature. Krakat et al. in their studies observed that methane generation from energy crops at a higher temperature of $60^{\circ} \mathrm{C}$ resulted in dominance of hydrogenotrophic Methanobacteriales as compared to acetoclastic methanogens among the microbial communities with a corresponding increase in methane production in thermophilic biogas fermentor [68]. These workers reported that their observation contradicts the common anaerobic digestion model 1 (ADM1) which states that two-thirds of methane is obtained from the acetoclastic methanogens and one-third from hydrogenotrophic methanogens [69]. The negative value of ( $\Delta G^{0}$ and the positive value of $\left(\Delta H^{0}\right)$ obtained for the biomethanization process in this study would suggest in accordance with the observation of Krakat et al. that at higher temperature or thermophilic temperature $\left(50-60^{\circ} \mathrm{C}\right)$ the forward reaction was highly favoured (i.e. increased product formation, in this case, biomethane) as well as the predominance of hydrogenotrophs in the biodigester which perhaps could mostly be responsible for the biomethane generation through the hydrogenotrophic methanogenesis pathway than through the acetoclastic methanogenesis pathway [68].

The activation energy of biogas production from the biomethanization of mixed animal wastes co-digested with pineapple fruit waste and inoculum at different temperature was obtained from the application of Arrhenius form of equation (Eq. (22)).

$$
k=A e^{-\frac{E_{a}}{R T}}
$$

Where, $\mathrm{A}$ and $E_{a}$ are the Arrhenius parameters which stand for frequency factor or pre-exponential coefficient $\left(\mathrm{min}^{-1}\right)$ and activation energy $(\mathrm{J} / \mathrm{mol})$, respectively. $k$, is the rate constant $\left(\mathrm{min}^{-1}\right), \mathrm{R}$ is the molar universal gas constant 
(8.314 $\left.\mathrm{J} \mathrm{mol}^{-1} \mathrm{~K}^{-1}\right)$ and $\mathrm{T}$ is the absolute temperature $(\mathrm{K})$. By taking the natural logarithm, Eq. (22) can be expressed as:

$$
\ln k=\ln A-\frac{E_{a}}{R T}
$$

The activation energy $\left(E_{a}\right)$ was obtained from the plot of $\ln \mathrm{k}$ against $1 / \mathrm{T}$ as shown in Fig. (6).

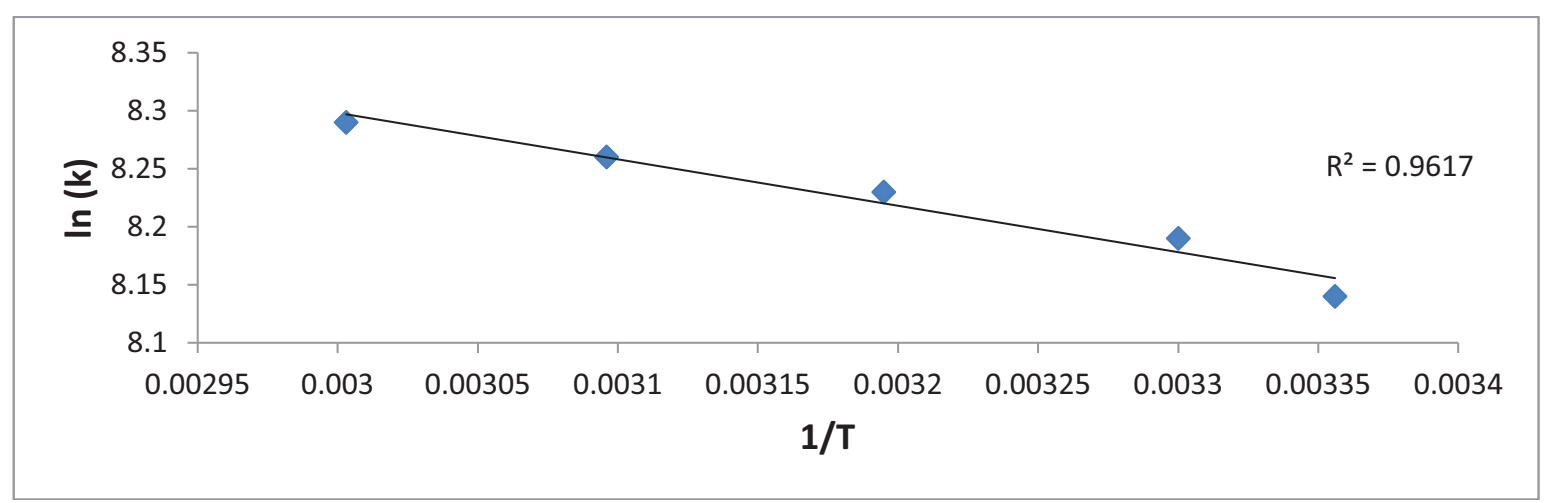

Fig. (6). Arrhenius plot of biogas from biomethanization of mixed animal wastes co-digested with pineapple fruit waste and chicken rumen at different temperature.

The activation energy was estimated to be $3.324 \mathrm{~kJ} / \mathrm{mol}$. The positive value of $E_{a}$ that the biomethanization process is endothermic in nature and thus favoured by moderate to high temperature.

\section{CONCLUSION}

It can be concluded that cumulative biogas yield with its biomethane content obtained from the biomethanization of cattle manure, pig manure and chicken manure mixture co-digested with pineapple fruit waste (co-substrates) and content of chicken-gizzard (as inoculums), can generally be influenced positively or negatively by variation in the values or amount of feed/inoculum ratio, temperature and agitation speed. The cumulative biogas yield and its biomethane content relatively increased with increase in feed/inoculum ratio and temperature. Anaerobic digestion can occur in the mesophilic as well as in the thermophilic range. Agitation speed of 30 to 70 rpm enhances cumulative biogas yield in the range of 5.3 to $31.3 \%$ as well as the biomethane content in the range of 4.3 to $26.1 \%$ in comparison with biomethanization without agitation. Agitation speed above $30 \mathrm{rpm}$ gradually decreases the cumulative biogas yield and its biomethane content. Modified Gompertz and Exponential Rise to Maximum kinetic growth models can be used to simulate cumulative biogas/biomethane production from the biomethanization of cattle manure, pig manure and chicken manure mixture co-digested with pineapple fruit waste (co-substrates) and content of chicken-gizzard. Biomethanization of cattle manure, pig manure and chicken manure mixture co-digested with pineapple fruit waste (cosubstrates) and content of chicken-gizzard is thermodynamically feasible, spontaneous and endothermic in nature. The activation energy (E) of the biomethanization process was found to be $3.324 \mathrm{~kJ} / \mathrm{mol}$, indicating the endothermic nature of the biomethanization process. The negative values of $\left(\Delta G^{0}\right)$ and positive value of $\left(\Delta H^{0}\right)$ suggest that at higher temperature or thermophilic temperature $\left(50-60^{\circ} \mathrm{C}\right)$ hydrogenotrophs might be predominant in the biodigester and perhaps could mostly be responsible for the biomethane generation through the hydrogenotrophic methanogenesis pathway than through the acetoclastic methanogenesis pathway. The specific heat capacity at constant volume and constant pressure, specific internal energy and specific enthalpy of the biogas and biomethane content increased with increase in temperature.

\section{ETHICS APPROVAL AND CONSENT TO PARTICIPATE}

Not applicable.

\section{HUMAN AND ANIMAL RIGHTS}

No Animals/Humans were used for studies that are base of this research. 


\section{CONSENT FOR PUBLICATION}

Not applicable.

\section{CONFLICT OF INTEREST}

The authors confirm that the content of this article has no conflict of interest.

\section{ACKNOWLEDGEMENTS}

The authors would like to thank the technical staff of the Central Research Laboratory of Ladoke Akintola University of Technology, Ogbomoso for the access, help, support and use of the laboratory facilities

\section{REFERENCES}

[1] Manyi-Loh CE, Mamphweli SN, Meyer EL, Okoh AI, Makaka G, Simon M. Microbial anaerobic digestion (bio-digesters) as an approach to the decontamination of animal wastes in pollution control and the generation of renewable energy. Int J Environ Res Public Health 2013; 10(9): 4390-417.

[2] Cassidy DP, Hirl PJ, Belia E. Methane production for ethanol coproduction in anaerobic SBRS. Water Sci Technol 2008; 58(4): 789-93.

[3] Xiao W, Yao W, Zhu J, Miller C. Biogas and CH4 productivity by co-digesting swine manure with three crop residues as an external carbon source. Bioresour Technol 2010; 101: 4042-7.

[4] Tiehm KN, Zellhorn M, Neis U. Ultrasonic waste activated sludge disintegration for improving anaerobic stabilization. Water Res 2001; 35(8): 2003-9.

[5] Ogunleye OO, Aworanti OA, Agarry SE, Aremu MO. Enhancement of animal waste biomethanation using fruit waste as co-substrate and chicken rumen as inoculums. Energy Sources, Part A: Recov. Utiliz Environ Effects 2016; 38(11): $1653-60$.

[6] Sreenivas R, Retter RA, Hobbs PJ. Effect of biomass hydrolysis on biogas production. Process Biochem 2010; 28(2): 119-23.

[7] Umar HS, Firdausi BR, Sharifah RW, Fadimtu M. Biogas production through co-digestion of palm oil mill effluent with cow manure. Nig J Basic and Appl Sci 2013; 21(1): 79-84.

[8] Angelidaki I, Ahring BK. Anaerobic thermophilic digestion of manure at different ammonia loads: effect of temperature. Water Environ Res 1994; 28(3): 727.

[9] Song YC, Kwon SJ, Woo JH. Mesophilic and thermophilic temperature co-phase anaerobic digestion compared with single-stage mesophilicand thermophilic digestion of sewage sludge. Water Environ Res 2004; 38(7): 1653.

[10] Sathish S, Vivekanandan S. Optimization of different parameters affecting biogas production from rice straw: An analytical approach. IJSSST 2011; pp. 78-84.

[11] Usman MA, Olanipekun OO, Ogunbanwo OA. Effect of temperature on biogas production from lignocellulosic substrate. Int J Res Chem and Environ 2012; 2: 68-71.

[12] Manjula DG, Mahanta P. Comparison of kinetic models for biogas production rate from saw dust. Int J Res Eng Technol 2014 ; 3: $248-53$.

[13] Wang X, Lu X, Li F, Yang G. Effects of temperature and carbon-nitrogen (C/N) ratio on the performance of anaerobic co-digestion of dairy manure, chicken manure and rice straw: Focusing on ammonia inhibition. PLoS One 2014; 9(5): e97265. [http://dx.doi.org/10.1371/journal.pone.0097265]

[14] Santosh Y, Sreekrishman TR, Kohli S, Rana V. Enhancement of biogas production from solid substrates using different techniques- a review. Bioresour Technol 2004; 95: 1-10.

[15] Naphon K, Hussaro K, Sombat T. Effect of with/without agitation of agricultural waste on biogas production from anaerobic co-digestion-A small scale. Am J Environ Sci 2014; 10(1): 74-85.

[16] Brehmer M, Eppinger T, Kraume M. Influence of rheology on the flow pattern in stirred biogas plants. Chem Ing Tech 2012; 84: 2048-56.

[17] El-Bakhshwan MK, Abd El-Ghafar SM, Zayed MF, El-Shazly AE. Effect of mechanical stirring on biogas production efficiency in large scale digesters. J Soil Sci and Agric Eng 2015; 6(1): 47-63.

[18] Karim K, Hoffmann R, Klasson T, Al-Dahhan MH. Anaerobic digestion of animal waste: Waste strength versus impact of mixing. Bioresour Technol 2005; 96: 1771-81.

[19] Nandi R, Saha CK, Huda MS, Alam MM. Effect of mixing on biogas production from cow dung. Eco-friendly Agril J 2017 ; 10 (2): 7-13.

[20] Desai M, Patel V, Madamwar D. Effect of biomethanation of cheese whey - poultry waste - cattle dung. Environ Pollut 1994; 83: 311-5.

[21] Angelidaki VA. Anaerobic degradation of solid material: Importance of initiation centers for methanogenesis, mixing intensity, and 2D distributed model. Biotechnol Bioeng 2005; 89(1): 13-122.

[22] Kaparaju P, Buendia I, Ellegaard L, Angelidakia I. Effects of mixing on methane production during thermophilic anaerobic digestion of manure: Lab-scale and pilot-scale studies. Bioresour Technol 2008; 9: 4919-28.

[23] Tian Z, Chauliac D, Pullammanappallil P. Comparison of non-agitated and agitated batch, thermophilic anaerobic digestion of sugar beet 
tailings. Bioresour Technol 2013; 129: 411-20.

[24] Karima K, Hoffmanna R, Klassonb T, Al-Dahhana MH. Anaerobic digestion of animal waste: Effect of mode of mixing. Water Res 2005; 39: 3597-606.

[25] Hoffmann RA, Garcia ML, Veskivar M, Karim K, Al-Dahhan MH, Angenet LT. Effect of shear on performance and microbial ecology of continuously stirred anaerobic digesters treating animal manure. Biotechnol Bioeng 2008; 100: 38-48.

[26] Batista APD, Van Weelden MB, Andersen DS. Agricultural and Biosystems Engineering Conference Proceedings and Presentations. In: Impact of Temperature and Mixing on Methane Production Rates of Swine Manures obtained from Deep pit Storages, Kansas City 2013.

[27] Narayani TG, Gomathi Priya P. Biogas production through mixed fruit wastes biodegradation. J Sci Ind Res 2012; 71: 217-20.

[28] Prakash EV, Singh LP. Biomethanation of vegetable and fruit waste in co-digestion process. Int J Emerging Technol Adv Eng 2013; 3(6): 493-5.

[29] Otun TF, Ojo OM, Ajibade FO, Babatola JO. Evaluation of biogas production from the digestion and codigestion of animal waste, food waste and fruit waste. Int J Energy and Environ Res 2015; 3(3): 12-24.

[30] Oliveira JV, Alves MM, Costa JC. Optimization of biogas production from Sargassum sp. using a design of experiments to assess the codigestion with glycerol and waste frying oil. Bioresour Technol 2015; 175: 480-5.

[31] Quiroga G, Castrillon L, Nava YF, et al. Effect of ultrasound pre-treatment in the anaerobic co-digestion of cattle manure with food waste and sludge. Bioresour Technol 2014; 154: 74-9.

[32] Xie S, Wu G, Lawlor PG, Frost JP, Zhan X. Methane production from anaerobic co-digestion of the separated solid fraction of pig manure with dried grass silage. Bioresour Technol 2012; 104: 289-97.

[33] Matheri AN, Belaid M, Seodigeng T, Ngila CJ. Modelling the Kinetic of Biogas Production from Co-digestion of Pig Waste and Grass Clippings. Proceedings of the World Congress on Engineering. London, U.K. 2016.

[34] Owamah HI, Alfa MI, Dahunsi SO. Optimization of biogas from chicken droppings with Cymbopogon citratus. Renew Energy 2014; 68: 366-71.

[35] Imam MF, Khan MZ, Sarkar MA, Ali SM. Development of biogas processing from cow dung, poultry waste, and water hyacinth. Int J Natural and Appl Sci 2013; 2(1): 13-7.

[36] Borowski S, Domanski J, Weatherley L. Anaerobic co-digestion of swine and poultry manure with municipal sewage sludge. Waste Manag 2014; 34(2): 513-21.

[37] Sebola MR, Tesfagiorgis HB, Muzenda E. Methane production from anaerobic codigestion of cow dung, chicken manure, pig manure and sewage waste. Proceedings of the World Congress on Engineering. London, U.K. 2015.

[38] Pandey PK, Ndegwa PM, Soupir ML, Alldredge JR, Pitts MJ. Efficacies of inocula on the startup of anaerobic reactors treating dairy manure under stirred and unstirred conditions. Biomass Bioenergy 2011; 35(7): 2705-20.

[39] Masse DI, Masse L, Verville A, Bilodeau S. The start-up of anaerobic sequencing batch reactors at $20^{\circ} \mathrm{C}$ and $25^{\circ} \mathrm{C}$ for the treatment of slaughterhouse wastewater. J Chem Technol Biotechnol 2001; 76: 393-400.

[40] Xu J, Mustafa AM, Sheng K. Effects of inoculum to substrate ratio and co-digestion with bagasse on biogas production of fish waste. Environ Technol 2016; 1-6. [http://dx.doi.org/10.1080/09593330.2016.1269837]

[41] Pessuto J, Scopel BS, Perondi D, Godinho M, Dettmer A. Enhancement of biogas and methane production by anaerobic digestion of swine manure with addition of microorganisms isolated from sewage sludge. Process Saf Environ Prot 2016; 104: 233-9.

[42] Aragaw T, Andargie M, Gessesse A. Co-digestion of cattle manure with organic kitchen waste to increase biogas production using rumen fluid as inoculums. Int J Phy Sci 2013; 8(11): 443-50.

[43] Tang GL, Huang J, Sun ZJ, Tang QQ, Yan CH, Liu GQ. Biohydrogen production from cattle wastewater by enriched anaerobic mixed consortia: Influence of fermentation temperature and pH. J Biosci 2008; 106: 80-7.

[44] Sakar S, Yetilmezsoy K, Kocak E. Anaerobic digestion technology in poultry and livestock waste treatmen. Waste Manag Res 2009; 9(27): 3-18.

[45] St-Pierre B, Wright AD. Metagenomic analysis of methanogen populations in three full- scale mesophilic anaerobic manure digesters operated on dairy farms in Vermont, USA. Bioresour Technol 2013; 138: 277-84.

[46] Iyagba ET, Ibifuro AM, Yahaya SM. Full length research paper; the study of cow dung as co-substrate with rice husk in biogas production. Sci Res Essays 2009; 4(9): 861-6.

[47] AOAC. Official methods of analysis. 15th ed. Washington, DC: Association of Official Analytical Chemists 1990.

[48] AWWA, WPCF Standard Methods for the Examination of Water and Wastewater. 17th ed. Washington, D.C.: American Public Health Association 1998.

[49] Banks CJ, Heaven S. Optimisation of biogas yields from anaerobic digestion by feedstock type. In: Wellinger A, Murphy J, Baxter D, Eds. The biogas handbook Science, production and applications Woodhead Publishing Series in Energy: Number 52. UK: IEA Bioenergy. Woodhead, Publishing Limited 2013. 
[50] Chandra R, Takeuchi H, Hasegawa T. Methane production from lignocellulosic agricultural crop wastes: A review in context to second generation of biofuel production. Renew Sustain Energy Rev 2012; 16: 1462-76.

[51] Adeniran KA, Ahaneku IE, Itodo IN, Rohjy HA. Relative effectiveness of biogas production using poultry wastes and cow dung. Agric Eng Int: CIGR Journal 2014; 16(1): 124-32.

[52] Latinwo GK, Agarry SE. Modelling the kinetics of biogas production from mesophilic anaerobic co- digestion of cow dung with plantain peels. Int J Renew Energy Dev 2015; 4(1): 55-63.

[53] De Gioannis G, Muntoni A, Cappai G, Milia S. Landfill gas generation after mechanical biological treatment of municipal solid waste. Estimation of gas generation rate constants. Waste Manag 2009; 29: 1026-34.

[54] Lo HM, Kurniawan TA, Sillanpaa ME, Pai TY, Chiang CF, et al. Modelling biogas production from organic fraction of MSW co-digested with MSWI ashes in anaerobic bioreactors. Bioresour Technol 2010; 101: 6329-35.

[55] Budiyono IN, Widiasa SJ, Sunarso O. The kinetic of biogas production rate from cattle manure in batch mode. Int J Chem Biol Eng 2010; 10(1): $68-75$.

[56] Yusuf MO, Debora A, Ogheneruona DE. Ambient temperature kinetic assessment of biogas production from co-digestion of horse and cow dung. Res Agric Eng 2011; 57(3): 97-104.

[57] Roger GF, Mayhew YR. Engineering Thermodynamics (ELBS), Longman, Hong Kong, Hong Kong, 1988.

[58] Rajput RK. Thermal Engineering. New Delhi: Laxmi Publications Ltd 2003.

[59] Yaru SS, Adegun IK, Akintunde MA. Determination of thermo-physical properties of forty day incubation cattle dung biogas. App Sci Report 2014; 8(3): 168-74.

[60] Manik D, Vikram P, Datta M. Effect of temperature and retention time on biomethanation of cheese whey poultry waste-cattle dung. J Environ Pollut 1994; 83: 311.

[61] Varel V, Hashimoto AG, Chen YR. Effect of temperature and retention time on methane production from cattle waste. Appl Environ Microbiol 1980; 40: 217.

[62] Hashimoto AG, Varel V, Chen YR. Ultimate methane yield from beef cattle manure: effect of temperature, ration constituents, antibiotics and manure age. J Agric Wastes 1981; 3: 241.

[63] Parker D. Demonstration of biogas production using low moisture content beef cattle manure,. West Texas A \& M University Canyon. West bioenergy 2000; pp. TX 79015. 14-23

[64] Muthanna A, Muhul V. Effect of mixing and scale on the performance and hydrodynamics of anaerobic digesters. Biochem Technol 2006; 32: 81-724.

[65] Okuo DO, Waheed MA, Bolaji BO. Evaluation of Biogas Yield of Selected Ratios of Cattle, Swine, and Poultry Wastes. Int J Green Energy 2016; 12(4): 366-72.

[66] Eastop TD, McConkey A. Applied Thermodynamics for Engineering Technologists, S I Units. 5th ed. Singapore: ELBS with Longman Publishers 1996.

[67] Nautiyal P, Subramanian KA, Dastidar MG. Kinetic and thermodynamic studies on biodiesel production from Spirulina platensis algae biomass using single stage extraction-transesterification process. Fuel 2014; 135: 228-34.

[68] Krakat N, Westphal A, Schmidt S, Scherer P. Anaerobic digestion of renewable biomass: Thermophilic temperature governs methanogen population dynamics. Appl Environ Microbiol 2010; 76(6): 1842-50.

[69] Batstone DJ, Keller J, Angelidaki I, et al. The IWA anaerobic digestion model No.1 (ADM1). Water Sci Technol 2002; 45 : 65-73.

(C) 2017 Aworanti et al.

This is an open access article distributed under the terms of the Creative Commons Attribution 4.0 International Public License (CC-BY 4.0), a copy of which is available at: (https://creativecommons.org/licenses/by/4.0/legalcode). This license permits unrestricted use, distribution, and reproduction in any medium, provided the original author and source are credited. 